The Phantom of the Good Soldier Švejk in the Czech Army Accession to NATO (2001-2002) Author(s): Hana Cervinkova

Source: International Journal of Politics, Culture, and Society, Vol. 22, No. 3, 1989 and Beyond: The Future of Democracy (Sep., 2009), pp. 359-371

Published by: Springer

Stable URL: https://www.jstor.org/stable/25621930

Accessed: 07-04-2020 11:08 UTC

JSTOR is a not-for-profit service that helps scholars, researchers, and students discover, use, and build upon a wide range of content in a trusted digital archive. We use information technology and tools to increase productivity and facilitate new forms of scholarship. For more information about JSTOR, please contact support@jstor.org.

Your use of the JSTOR archive indicates your acceptance of the Terms \& Conditions of Use, available at https://about.jstor.org/terms 


\title{
The Phantom of the Good Soldier Švejk in the Czech Army Accession to NATO (2001-2002)
}

\author{
Hana Cervinkova
}

Published online: 25 July 2009

C Springer Science + Business Media, LLC 2009

\begin{abstract}
The article is based on the author's ethnographic fieldwork in the Czech Armed Forces (2001-2002) in which she focused on the process of military professionalization-a set of extensive institutional reforms initiated upon the Czech Republic's accession to NATO. She shows that these reforms were not limited to the military sector and involved efforts on the part of the state officials and the media to change the position of the military in the public sphere and culture. The goal of these changes was to bring the image of seriousness to the discredited Czech military, a process that demanded the obliteration of the cultural idiom of Svejk-a literary hero of the 1920s novel by Jaroslav Hašek and the representation of a peaceful resistance to war and military violence. In the course of the twentieth century, Švejk has become one of the most pervasive cultural references of the popular laughter at oppressive military power and has been a leading cultural idiom for the Czechs during the 30 years of German and Soviet military occupations. The article shows how the current official efforts at changing the image of the Czech military focus on the obliteration of Svejk's cultural idiom, bringing him so frequently to the public discourse that they produce a phantom-like effect in which Svejk has come to haunt the process directed at his expurgation. The established cultural idiom of skepticism toward the army and military bureaucracy thus challenges the transition from communism to democracy and questions the reliance on military force, the imagery of violent conflicts, and just wars as necessary tools of politics.
\end{abstract}

Keywords Military $\cdot$ Švejk $\cdot$ Professionalization $\cdot$ Postcommunist transformation $\cdot$ NATO

\section{Professionalizing the war machine}

This paper draws on my ethnographic fieldwork in the Czech Armed Forces, which I conducted between February 2001 and June 2002 and in which I focused on studying the process of military professionalization - an extensive institutional reform, which accompa-

H. Cervinkova ( $\square)$

International Institute for the Study of Culture and Education, University of Lower Silesia-DSW, Wrocław, Poland

e-mail: hana@post.pl 
nied the country's accession to NATO (Cervinkova 2006a). Military professionalization promised to abolish the very unpopular law of compulsory male conscription and to create a small, mobile, and effective all-volunteer force; the new professional military, as opposed to the large conscription army of the Soviet times, was to be able to be "at the right place at the right time" and to consist of professional practitioners in the military craft who, equipped with top-level technology and English language skills, would be deployable in international and domestic operations of utmost difficulty (Cervinkova 2006b; Ministry of Defense of the Czech Republic, 2001, 2002a, b, c). The process of professionalization involved the quantitative reduction of forces and technology and promised a qualitative improvement of work conditions and competencies for the practitioners-a better pay, more advanced technology, possibilities to acquire superior technical and linguistic skills, sustained contact with the Western world, and a more transparent career ladder for advancement. The very shift toward a professional military was implemented from within the Czech military principally through the Law on Professional Soldiers of 2001, which encouraged older officers, who have served most of their lives under the socialist regime and were deemed unusable to the new military order, to leave service by offering them very convenient retirement conditions (Cervinkova 2005, 2009; Ministry of Defense of the Czech Republic 1999). Nevertheless, the professionalization of the military produced an upheaval within the military, and it is this upheaval that has been the main focus of my fieldwork (Cervinkova 2005).

Professionalization, of course, is a process whose implications have by far exceeded the limits of the military sector. Rather than a purely institutional reform, the Czech military professionalization could be seen as a technology of a new rationality which sought to reorganize the relationship between the state, society, and the traditional institution of legitimate violence (Cervinkova 2006a). According to this new rationality, the larger apparatus of power that Deleuze and Guattari call the war machine is to assume a different and more prominent position vis-à-vis the state and society (Deleuze and Guattari 1987). In the post-communist Czech context, this repositioning of the war machine was instigated and assisted by the regional processes of democratization and NATO integration, which have exerted pressures on the Czech state to launch effective reforms in the military and the security sector (Cottey et al. 2002; Gabal 2001, 2002; Gabal et al. 2002; Sedivý 1999; Simon 1999; Spurný 1998, 2001; Ulrich 1999, 2002; Žantovský 1999). Using "professionalization" as a powerful signifier, a trendy catchword, the Czech state sought to modernize a technologically obsolete post-Soviet military institution and at the same time to convince Czech society to replace its culturally entrenched, generally skeptical attitude toward things military with a new respect and seriousness (Ministry of Defense of the Czech Republic 2002a, b, c; Simon 1985). Such repositioning of the "war machine" in the Czech political and social life, however, required changes that challenged some of the pillars of the Czech national culture, and it did not go uncontested. Instead, in the liminal period of the post-communist state formation, the process of military professionalization was characterized by paradoxes and ruptures, which often produced a grotesque effect as the futuristic fantasies of "professionalization" clashed with both the key Czech cultural syndrome and the emerging post-Soviet reality. One of the most prominent grotesque moments that the campaign for military professionalization produced was an intriguing form of cultural exorcism, which I will describe below.

\section{Introducing Švejk}

Under communism, or what is more frequently referred to as "real socialism," the Czechoslovak People's Army (CPA) served as the pawn to the Soviet colonial empire; the 
CPA as an institution of the "cold war" never fought in any actual war, and instead of defending the national territory, it was passive during the takeover by the Warsaw Pact invasion of Czechoslovakia in 1968. Propounded by the earlier history of passive submission under the German occupation during WWII, the Czech national military has served as the object of popular jokes rather than a source of national pride and respect for the Czechs. Due to the military's immediate bond to the communist party, popular jokes about the military in fact targeted the communist state. One of the most pervasive cultural references of the popular laughter at the military and at the socialist state's power was the Good Soldier Švejk, the hero of the 1920s fabulous Czech anti-war novel by Jaroslav Hašek and the representation of a peaceful resistance to war (Hašek 1973).

Švejk, a literary character born out of Hašek's own experience with war, is a rheumatic trader in stray dogs from the Prague periphery, where he starts his wartime adventures by volunteering to fight Serbs as a soldier in the imperial Austrian army. Svejk spends much time ardently professing his patriotism and devotion to the monarchy and its war campaign, but his actions behind enemy lines actually impede the achievement of his proclaimed objective. Because of his peculiar behavior, which his superiors name "idiotic" (a designation Švejk cheerfully endorses), the Good Soldier Švejk, despite his extreme diligence and eagerness, never manages to complete what his superiors want him to do. While literally and perfectly executing orders assigned to him, the results of his actions are unfailingly disastrous for the war effort. Svejk speaks common Czech, and in this vernacular, he answers to almost every reprimand of his commanders with a story he has once heard. These stories of everyday life, a grotesque mixture of hilarity, cruelty, and violence, are Švejk's most powerful weapon. It is through them that this evidently naïve soldier disarms his superiors, and while never really mentioning the war, let alone engaging in it, we are certain in our laughter that he is fully and at every moment victorious over the war machine.

For example, when Švejk gets reassigned to a new boss, Lieutenant Lukáš, who prides himself in hating his batmen, he must listen to a long litany of threats and warnings. In his welcoming speech, Lukáš tells Švejk that he requires his subordinates to always tell him the truth and that they must fulfill his orders without grumbling. Just as he is telling Svejk, "If I say to you: 'Jump into the fire', then you must jump into the fire, even though you don't want to," he notices that Švejk is not looking at him and when he asks him why, Švejk answers in a gentle, good-natured tone: "'Humbly report, sir, there's a Harz canary there'. And having interrupted in this way the flow of the lieutenant's words Švejk adopted a military stance and looked him straight in the eyes without blinking. The lieutenant wanted to say something sharp, but observing the innocent expression on Švejk's face said nothing more than 'The chaplain recommended you as a frightful idiot and I think he was not wrong"'. Without hesitation, Švejk immediately interjects with a story: "Humbly report, sir, he certainly was not wrong. When I was serving as a regular I got a complete discharge for idiocy and for patent idiocy into the bargain. In our regiment only two of us were discharged in this way, me and a Captain von Kaunitz. And whenever that captain went out in the street, if you'll pardon me, sir, he always at the same time picked his left nostril with his left hand, and his right nostril with his right hand, and when he went with us to parade ground he always made us adopt a formation as though it was going to be a March past and said: 'Men, ahem, remember, ahem, that today is Wednesday, because tomorrow will be Thursday, ahem'" (Hašek 1973, p. 168). After Švejk's story, the lieutenant is disarmed, his rhythm and composure are out of balance, he is clearly at a loss: "Lieutenant Lukáš shrugged his shoulders, like a man who did not know how to express a certain thought and could not immediately find words to do so. He went from the door to the window on the other side of the room past Svejk and back again. All this time Švejk did 'eyes right' or 
'eyes left' wherever the lieutenant was and did it with such a marked expression of innocence on his face that the lieutenant lowered his gaze to the carpet and said something which had no connection at all with Švejk's observation about the stupid captain. 'Yes. With me there's got to be order, cleanliness and no lying. I like honesty. I hate lies and punish them mercilessly. Do you understand?"” To which Svejk responds: "Humbly report, sir, I understand. There's nothing worse than when someone tells a lie. As soon as he starts getting tied up he's done for. In a village behind Pelhrimov there was once a teacher called Marek..." (Hašek 1973, pp. 168-169) continuing with another story that distracts the lieutenant who realizes the gradual loss of his authority.

Švejk's victory over the Lieutenant points to the possibility of winning over the absurdities of military order through words and humor-signifying the potential of popular non-violent resistance to impair the state apparatus of legitimate violence, which Deleuze and Guattari call the war machine. During the four decades of so-called real socialism (1946-1989) and especially during the last two decades of Soviet military occupation (19681991), Svejk has performed a double role; the militarily impotent Czech army, which remained passive during the occupation of Czechoslovakia by the Warsaw Pact forces, has been seen both by the Czechs and outsiders as the army of Svejk, and by extension, the Czechs were a nation of Švejks living under a military occupation uncontested by its own national army. Yet, this apparently self-critical, even self-mocking, identification contained a subversive element, as an important feature of the story of the Good Soldier Svejk is his ultimate victory over the war machine by subverting its seriousness through the comic principle. Therefore, consistent with the logic of cultural intimacy, Svejk has functioned for the outside world as the Czechs' self-deprecating label, while providing at home a crucial social bond, a common reference that brought people together (Herzfeld 1997).

Far from being just a literary figure, the Good Soldier Švejk has, over the years, left the world of the imaginary, the world of shadows. Like a phantom, he is often evoked by the Czechs through a particular discursive contraption-a utterance, a kind of a magical spell: "Švejkáma," “Švejkovat,"or “Švejkoviny." "Švejkovat”(to do things like Švejk), Švejkoviny (ridiculous activities reminiscent of Švejk's performance), and "Švejkáma" (situation evocative of the grotesque quality of Švejk's legendary escapades) are usually spoken to mark situations of absurdity, farce, ambiguity, and contradiction. Most obviously, these are situations in which the common sense of a smaller and less powerful subject confronts the mad rationality of a larger and powerful body. However, finally, the weaker wins over the potent against all odds by virtue of the comic principle and the accompanying laughter. Laughter is what defeats the adversary and brings victory to the powerless. Not surprisingly, "Švejkáma," "Švejkovat," or "Švejkoviny" are expressions often associated with the institution of the military, where the rules of blind discipline and mechanical order based on seniority and hierarchy defy those of human reason. I would sometimes hear "That's Švejkárna, man!," by a recruit caught in the middle of two mutually contradictory orders issued by his superiors. The recruit, by trying to execute these conflicting commands literally but with sorry effects for the military institution, would then be said to "Švejkovat" or to have been engaged in activities summarized under the term of "Švejkoviny."

However, the terms, "Švejkárna," "Švejkovat," or "Švejkoviny" are most often applied to situations that surpass the level of individual conduct. The post-communist government officials and the Czech press have been very concerned with the poor reputation of the Czech military inside and outside of the country, which seemed to impede the country's efforts to become a part of the NATO's transnational political and military alliance. The politicians and journalists have repeatedly evoked the name of the Good Soldier to criticize the institution of the Army of the Czech Republic for its low level of preparedness and the 
slow pace of post-Soviet reforms. In a feature article published by a leading Czech weekly shortly after the September 11th events in the USA entitled, "Rambos versus Svejks: Why Do People Laugh at Our Military?," the author describes the Czech military as composed of a "handful of elite gunmen and thousands of useless men to fill the ranks"-few elite Rambos among many Švejks (Vrána 2001). In his reckoning, the Rambos are "professionals" in the use of military violence and "to them belongs the future." Their chief attributes are their superior technical and physical skills, which, combined with the knowledge of English and personal qualities emphasizing self-confidence and professional detachment, make them readily deployable in key international operations. The participation of these professionals in the operations conducted outside the borders of the country brings a good name to the Czech military - a reputation that the country's leaders desperately crave to gain credibility among their new allies.

\section{Writing against Švejk}

Since one of the important goals of the professionalization campaign was to bring the national war machine into a prominent position within the Czech state and society, various political actors have tried to diminish the position of Svejk - along with its subversive rolein national culture. Articles with titles, such as "Let's Put an End to Švejkism!" published shortly before the Czech Republic joined NATO, pleaded with the Czech public, at the time still hardly enthusiastic about the upcoming accession to NATO Alliance, to become serious about military and security affairs and consider all the advantages of NATO membership. According to the journalist, a major obstacle to changing people's attitude toward the military is, of course, nobody else but Švejk! "[Š]vejkism," the author laments, "might have helped us survive through the bad times, which we have lived through in this century. But let us face the fact that Svejk is not a hero that should be followed, but a dog thief with the innocent face of a baby, who always took good car-of himself. Today, this kind of thinking will not bring us security" (Kopecký 1997).

Another author also warned the Czech politicians of Švejk's dangerous example in an article titled "Czech Diplomacy Cannot Take Pleasure in Svejkoviny." Criticizing the Czech politicians for their lack of diplomatic tact when dealing with their Western counterparts on the international stage, the writer declares, citing the hero himself: "Czech politicians should not listen to Svejk's assurances that 'spoiled reputation is but an inconsequential trifle,' since 'there are at least ten times more of those whose reputation is bad than those whose reputation is unspoiled.' It is likely," the author hopefully asserts, "that Czech diplomacy will not find pleasure in Svejkoviny. After all, this is no time for recklessness. The security umbrella of NATO will not open above the Czech state automatically" (Jégl 1997).

From the wand of one of the chief magicians in charge of spells banishing Svejk comes another example of this peculiar kind of witchcraft aimed at creating the air of solemnity toward the Czech Army. On the eve of the Czech Republic's accession to NATO, and shortly before the NATO launched its operations in former Yugoslavia, Michael Žantovský, the Chairman of the Senate Committee for International Affairs, Defense and Security wrote: "After bad experience, we [the Czechs] prefer to avoid big words and important dates. Let March 12, 1999 be an exception-we are leaving the vicious circle of modern Czech history, we are starting out on a new path. Our entry into NATO is giving us an unprecedented degree of security and geopolitical stability.... This decisive confirmation of our own freedom, however, also brings with it the commitment to protect the freedom of others.... We will probably soon have the opportunity to prove the value of our role in [allied 
security]. NATO is preparing a peace operation in Kosovo, [whose] success will depend on the contribution of all members, including the new ones. We could be seen as peacemakers, such as our soldiers in SFOR in Bosnia. Or we could be seen as Švejks" (Žantovský 1999).

In Žantovsky's appeal even more openly than in the other examples, Švejk is brought to life in response to an imagined gaze from NATO allies. And it is mostly in such relationship to the political and cultural outside that the hero survives in the Czech culture in his extraliterary form. In this shape, Svejk is a national fetish, a Czech voodoo doll-used to dislodge the cultural anxieties caused by external pressures associated with momentous shifts within the geo-political context of the country undergoing already a systemic transition. Svejk stands here as a traditional cultural idiom with respect to transnational alliances such as NATO and the EU-at the same time a symbol of cultural uniqueness and the cause for a national trauma and embarrassment. ${ }^{1}$ This is explicitly portrayed on the cover of the May 2001 issue of the EURO magazine, presenting the negative evaluation of the Czech Republic's compliance with the standards of the European Union. The coverpage drawing showed Švejk, the emblematic Czech announcing: "Humbly report, sir, that after ten years of marching to the West, we found ourselves near Sarajevo" (Žižka 2001a, b).

Václav Havel, a brilliant author of essays and plays dealing with Czechness under communism, has been himself an appreciative admirer of Švejk's magic. In a memento published to celebrate the end of Havel's presidential tenure, Adam Michnik writes how, in 1989, his fellow dissident and friend defined the essence of Czech character as oscillating "somewhere between Kafka's fatalistic melancholia and Svejk's self-deprecating irony" (Michnik 2003). As proof that he takes the cultural power of Svejk idiom seriously, Havel, toward the end of his presidential career, joined other leaders of the newly democratic Czech Republic in the war against Švejk to establish solemnity and respect toward the place of the military in Czech culture. Aware of the gravity of the task, which, if successfully completed, would provide access to the legitimizing membership in the select club of NATO states, Havel himself did not hesitate to resort to the means of black magic. In a speech given on the second anniversary of the Czech Republic's accession to NATO, Havel, in the company of NATO Secretary General George Robertson and two Czechs, Minister of Defense Jaroslav Vetchý and the Chief of the General Staff Jiři Sedivý, appealed to the nation: "We must show to the world that we are not Švejks any more, that our army is good and professional!" However, as in virtually all other attempts at banishing Švejk from the world of the living, the Good Soldier outsmarts his adversaries and ends up victorious. This is not just because of the society at large that is devoted to Švejk and his spiritual power. My research shows that even the military and political leaders, resolved to erase the connection between Švejk and the military institution, are not resistant to Švejk's disarming magic. And so the spell intended to expel Svejk's spirit was called back to life by Havel over pints of beer at The Švejk restaurant, U Kalicha ${ }^{2}$, Svejk's favorite Prague pub, where he starts his wartime literary adventure. The Svejk restaurant, U Kalicha, crowned by the portrait of Švejk and deeply associated with his legacy, was a location perfectly suited for the celebration of a major military anniversary (Rủžička 2001). As always, the effort to exorcise Švejk could not happen without his evocation which was however producing a grotesque effect in which the ghost haunts the very spectacles meant to purge him from cultural imagination.

\footnotetext{
${ }^{1}$ Elzbieta Matynia uses the concept of gender-based cultural idiom in her inspiring analysis of the failure of the post-communist transition in Poland to establish gender equality, see Matynia (2009).

${ }^{2}$ Information about the restaurant and Svejk's legacy is available at its official internet site - http://www. ukalicha.cz
} 


\section{Entering Švejk's Territory}

Like most phantoms, Švejk's power is concentrated in certain physical sites-pubs carrying his name, such as the aforementioned U Kalicha pub in Prague, or geographic locations that the Hašek's character visited in the course of his escapades. Nowhere is his influence more powerful, however, than in the place where he was born - the little fairytale-like village of Lipnice nad Sázavou-where Hašek settled upon his return from war and where he wrote his masterpiece. Today, in this town of 300 residents, the fictional character Švejk blends with the legacy of his author to produce particularly strange events with uncanny potential. Upon arrival, the road sign welcoming visitors to Lipnice is crowned with the popular imagery of the Good Soldier Svejk. And when you come into the town, many other cues remind you of whose place you are entering. There is Hašek's house, which has been made into a museum. Next to the house on the way to the castle, the author's bust looks down upon you from a pedestal. And at the end of the main street, there is a pub where the writer liked to spend his time and money he made by writing episodes of the Good Soldier Svejk, which he published in periodicals. Following family traces, Hašek's grandson recently purchased the tavern, which he now operates after he had retired as a colonel from the Czech military! And there is also Hašek's grave, visited by Lipnice citizens at night after their drinking orgies in the pub. In the epitaph engraved on the gravestone, the evidence of an operation that blends reality and fiction, a sentence in which the author merges with the character of his book: "Jaroslav Hašek -in memory of the author of Švejk." A local informant told me that, in the morning, one can often find pints of beer left on the tomb donated by intoxicated devotees of the author and his literary hero.

However, there are other signs that the spirits of Hašek and his Good Soldier Švejk are alive and well in Lipnice. Since 1958, the open-air amphitheater under the castle has been the site of Haškova Lipnice, a well-known annual festival of humor and satire attended by prominent Czech actors and comedians and by thousands of spectators from around the country. And of course, at least one performance in the festival was usually devoted to the Good Soldier Švejk.

In 1991, 2 years after communism had ended, the festival became an opportunity to celebrate a very different occasion-one that evoked tragic memories of the military invasion of 1968 - the Soviet Army finally left Czechoslovakia after more than 20 years of military occupation. Michael Kocáb, famous Czech rock musician turned politician, who was instrumental in the successful negotiation of the departure of the occupying forces, came to Lipnice that June accompanied by his American wife and transported by a chopper lent for this purpose by the Czech Air Force. At the conclusion of the evening full of music and comedy, Kocáb was to preside over a significant ritual. The poster that invited people to Lipnice that year announced this event proudly: "The Good Soldier Švejk will receive all things military from the last Soviet soldier into his own hands!" Indeed, the ceremony, administered by Kocáb and performed by two actors dressed respectively as a Soviet soldier and the Good Soldier Svejk, eventually did take place, watched among others by a General of the Czech Army prominent under the communist regime.

A local resident told me how, upon the completion of the ceremony in the amphitheater, he was entrusted with the task of giving a guided tour of Lipnice to a small group of important visitors, including Kocáb, his wife, and the Czech Army general in attendance of the celebrations. On the way to the hilltop castle where lavish refreshments and entertainment awaited the VIPs, however, the company was stopped in their climb by the sight of a large group of men, some of whom my informant recognized as town officials, absorbed in a serious and very confusing fistfight on the nearby meadow. Figuring that 
involvement of more people might only add to the already very unclear situation on the battlefield, our tour guide continued leading his visitors to the castle and explaining the fight in terms of local traditions. Finally, when full of gastronomic expectations, they arrived at the courtyard, they found out that all food and drinks had already been consumed. There was no doubt that it was the refreshments that motivated the gentlemen to fight. My informant, desperately trying to save the day, inquired with the warden about an expensive bottle of Russian vodka with which he had entrusted him anticipating the current turn of events. The explanation arrived by itself, without the exhausted keeper's effort as his wife stumbled onto the courtyard holding an empty bottle previously filled with the precious liquid. The fiasco had its conclusion in a local pub where the desperate guide took his guests for more modest refreshments only to be swept during the ascent to the second floor by a gentleman tossed down the stairs by his friends. As usual, the eventful night was concluded at Hašek's grave, who, as my informant told me confidently, "would have loved to see that day."

\section{Expurgating Švejk}

I arrived in Lipnice 10 years after this ceremony celebrating the departure of the occupying Soviet forces took place, invited by a Czech officer who served in a diplomatic position in the USA to attend a festival here. I was employed at the time by the Military University of the Army of the Czech Republic as a civilian researcher (February 2001-May 2002), focusing in my research on how transformation processes within the military following the Czech Republic's accession to NATO affected the occupational identity of the Czech military officers. Most of my friends whom I told of my plans to travel to Lipnice thought I was planning to attend Haškova Lipnice, the festival of humor and satire everyone knew about, but they were wrong. The festival I was invited to was called Azalea: A Salute to NATO, and was organized by members of the local branch of the Czech conservative Civic Democratic Party in partnership with the City of Norfolk, Virginia, to celebrate the Anniversary of the North Atlantic Treaty Organization. Military and political representatives were invited by electronic mail to "come and engage in serious debates about the state of our military and to celebrate NATO and our membership in it." At the end, the event was not attended by most of the key invitees, partly because just before it was held, an article published in an internet journal described Azalea as a conspiratory group of politicians, high-ranking military officers and former military people who were planning a coup d'etat against the Czech state (Mácha 2001). While for many military and political figures the piece served as a deterrent, for an anthropologist, albeit temporarily in military services, this was a tantalizing temptation.

I and my American anthropologist friend arrived early, and so we first took a tour of the city, paid our respects to Hašek's tomb, looked at his house and his bust, and then ordered lunch in the local restaurant called Bohemia (not to be confused with the Czech Crown pub of which Hašek was so fond), a location where the Azalea festival was to start. There were three flags outside of the restaurant-American, Czech, and NATO-and under the flag poles, a group of Czech conscripts in camouflage was pitching a canteen tent. When we walked into the immaculately clean restaurant with extremely polite waiters, we sat down at a table next to a glass cabinet containing a detailed model of a US air craft carrier with the following heading: "United States Navy: Auxiliary Navy/Marine Liege Post in Czech Republic, Lipnice nad Sázavou, The Czech Republic Member of NATO.” It was surely bizarre for the US Navy to have a post anywhere in the Czech Republic - a landlocked 
Central European country that has never had a fleet-but for the US Navy to a have a post in Lipnice nad Sázavou - a village of 300 people in the middle of Czech highlands, a region currently governed by the Communist Party and haunted by Svejk's spirit-that was absurdly grotesque!

As we were eating lunch, talking in muted voices about the possible presence of surveillance devices in the room, well-dressed business couples and few men in military uniforms started coming in the room. All of them passed by our table and disappeared in the rear part of the restaurant. After some time, I got up and went to see where they went, but the only people I could see were the well-dressed couples silently eating at one of the tables. They looked at me with suspicion and then returned to their plates. There was no sign of the military people that I saw coming through the place a short while ago-they simply disappeared! If we were not in Svejk's territory, I would have thought that the situation was rather Kafkaesque. I was then approached by a waitress who had been looking at me intently for some time. She asked me for my name, and then, she said that the gentlemen were already expecting me and asked me to follow her. Without any further information, she led us through a small door, which I had not previously seen into an upstairs room in which men sat in a circle, some dressed in uniforms, some in civilian clothes. There were cameras on the wall, and the entire atmosphere was so heavy with suspicion and caution that our prior speculations regarding the presence of surveillance apparatus now seemed embarrassingly accurate.

We sat down on chairs placed in the circle of approximately 20 people and joined in the "debate" that was just starting with a speech given by a middle-aged Czech man dressed in a white shirt and a cowboy tie. He welcomed the participants, a mixed group of civilians and military officers-all Czech-and thanked us for our serious concern with the military and security affairs of the country, which we duly demonstrated by attending the Azalea festival. He explained the connection of the Azalea festival in Lipnice to the same festival that was simultaneously starting at the US headquarters of NATO in Norfolk, Virginia, where the Czech Republic had a representative-a man I knew and who was responsible for inviting me to Lipnice. In his short speech, the man expressed his grave concern about the position of the military in the Czech political and public life and about the difficult situation inside of the military itself. The persistence of the problems related to the military and security affairs and the lack of the government's interest in changing the situation and in taking security and defense issues seriously were gravely endangering the membership of the Czech Republic in NATO. The concern of the Azalea group-an informal company composed of members and sympathizers of the conservative Civic Democratic Party- was to "change attitudes toward the military starting from a local level with people concerned with bringing seriousness to our partnership with NATO." 3

After the opening speech, the participants at first continued sitting quietly in the circle, looking at each other, occasionally glancing toward the cameras on the wall, but after a while, most of them, called by the organizer one by one, joined in the "discussion." Instead of a dialogic exchange, however, what followed was an ordered deliverance of announcements. Rather than a debate, the event resembled a performance, in which the actors presented a predictable sequence of observations that everyone in the room had already intimately known. I was not able to record the session fully, but from the notes that I took under the watchful eye of everybody in the room, the arguments were presented

\footnotetext{
${ }^{3}$ At this time, the Czech Republic was governed by the Social Democratic party, and the local administration in Lipnice was headed by the Communist Party. The Azalea group was composed most of conservative Civic Democratic Party members and sympathizers.
} 
approximately in the following sequence: First, the fact was established that the situation of the military in the Czech Republic was not good and the Social Democratic government was not interested in bringing about positive change. Second, the gravity of this situation was stressed, and it was asserted that because the Czech Republic was now a part of NATO, the continued disregard for military issues was bringing bad reputation to the Czech Republic in the eyes of the Allies. In conclusion, the participants searched for an explanation of this state of things, and here, two categories of arguments were offered, neither of which, of course, offered anything surprising or novel to anybody in the room: First, it was said that the problem lies in the military institution, which did not project a favorable public image. Second, it was difficult for the military to find support because disregard for things military was a chronic problem of the Czech society. The connecting link between both accounts was that the acute problems of the present were the results of the unwanted persistence of attachments to the past during this phase of post-communist transition; three categories of explanations for this were offered.

In the first segment of explanations, the problems within the military were caused by the presence of the old cadres whose thinking was still that of the past socialist regime past times. The older generation of officers was keeping the young progressive NATO-oriented professionals out of the top military ranks, thus preventing institutional change: "When one sees the situation, one is surprised that some of those highly qualified younger people are still staying in the military," a military officer said. "But they are staying, because they love their work-it is their passion. But they are surrounded by the majority, who are only interested in their monthly paychecks. That is how it is in the Czech military-Hodne chovnejch, málo tažnejch," the phrase that could be translated either as "Many animals for breeding, too few for work" or, depending on the zoological preference of the listener, either "Many studs and few geldings" or "Many bulls and few oxes." This was clearly a favorite saying of elite Czech military professionals who used it frequently in their interviews with me, summarizing the notorious problem of old cadres in a beautiful zoophilic image. The prevalence of older officers in the breeding sector of the military signified their connection to the senior leadership who used them to reproduce the older, Soviet type of military professional. In the lower sector were the stronger, mostly English speaking working animals, but their influence to bring about change was severely limited—both because of their positioning in the military hierarchy and because of their numeric disadvantage, framing them symbolically as castrated male animals.

The other category of explanations also stressed the persistence of the historical legacy as the main factor causing the low position of the military in Czech society, portraying it as a natural outcome of the national consciousness of the Czechs formed through centuries of foreign occupations and military defeats: "How could the Czechs be proud of being Czech and proud of their military as an institution that is to defend national interest and pride? During WWII, the Czech military did nothing. In fact, it was because it was given orders to do nothing, but people think it was the military's fault," said one officer. Another man, a journalist, added: "I think more than that, it was the Soviet occupation, when the military was again given orders not to act. They observed these orders and we were occupied again." And as if one century was not enough to shape the collective memory of the Czechs and to produce their hostility toward the military machine, another man pointed back to the historical events taking place almost four centuries back: "It all started with the White Mountain!" he said, reminding us of the infamous battle in 1621 , in which Bohemian nobility lost the kingdom to the Austrians, leading to the 300 years long colonization of Bohemia.

But then, as though the history of military defeats and misdeeds seemed insufficient to explain the lack of gravity and respect awarded to military institutions of the present time, 
one of the participants - a former elite officer-finally brought the main culprit to the stage: "There is no other nation that would be so negative toward its military as the Czechs," he said, with desperation. "The Czechs are a nation of Švejk. And because we have Švejk, nothing can change here." Therefore, in the denouement, after which the curtain was drawn, the hero who loomed heavily in the background of the plot was finally caught, brought to trial, and convicted. It was Svejk who provided the link between historical events and present problems-a literary figure whose persistent spectral existence was strengthened and awarded new agency by the very efforts for his expurgation.

When the debate ended, we were asked to go to the terrace to take a group photo. The picture, we were told, would be sent to the man in the USA, who could not attend the event, but of whom everyone knew. This promise was a reminder to the attendees of the omnipresent gaze of the outside world, for whom the performance was really staged. This sense of Big Eye, present through its very absence, constituted the moving force behind things and caused even the final desperate summons of the Good Soldier Svejk. Still, this was not the end, just a foreplay that established a bond of understanding between the participants, who would then be asked to banish collectively Švejk's phantom-the real cause of national adversity to the military institution.

We were then asked to walk to the open-air amphitheater underneath the Lipnice Castle, the traditional location of Haškova Lipnice, the famous festival of humor and satire that drew its popularity from its connection with the Good Soldier Švejk who was "born" here and whom the festival always honored in its theatrical productions. Today, however, we were participating in a spectacle, which did not have humor, grotesqueness, or satire intentionally included in its program. When we arrived, the place was already half-filled with people, many with small children. While waiting for this part of the festival to start, we watched conscripts attending to an army truck standing to the left of the stage. Then, suddenly, loud sounds of rifles and machine guns were heard from all around us. I looked toward the stage and saw that the soldiers on the truck were shooting approximately in our direction, and when I turned around, I saw men in camouflage rappelling from the rocks into the auditorium shooting at their opponents on the truck from machine guns. After they had landed, they continued shooting at each other across the audience, the men who descended from the rock gradually gaining position and moving closer to the stage. After approximately $30 \mathrm{~min}$ of fighting, with losses in lives on both sides, the remaining soldiers engaged in a one-on-one fight on the stage. After the army truck exploded and the scene was covered with bodies of "dead soldiers," there was a minute of silence. Finally, the dead stood up, joined the chorus of survivors, and together, they bowed to the audience, which rewarded them with hesitant applause. The organizers then went to a microphone and thanked the elite paratrooper unit from a nearby garrison for preparing the show, which, as we learned, was a staging of a successful battle of the Czech Army with some terrorists.

It was highly ironic that the spectacle intended to contribute to the new image of a serious Czech army produced overwhelmingly grotesque effects. The military violence, which was exhibited with excessive authenticity, was met with awkward hesitation on the part of the spectators. The sincerity with which the fight was staged was subverted into ridicule by the very context in which the performance took place. After all, it was a space saturated with a popular culture of laughter, which-as Bakhtin could have put it-disarms the power and empowers the harmless (Bakhtin 1984). The spectacle was clearly out of place, and the sense of awkwardness with which the performance was received stayed with us throughout the rest of the evening, which continued in the Bohemia restaurant. With a backdrop of the cabinet displaying the miniature model of a US air craft carrier, a night of spontaneous merriment and dancing to live music, as announced by the organizers, turned 
instead into an uncomfortably stiff dinner affair. Despite the organizers' efforts, none of the invited guests felt like dancing and Švejk, the phantom, was victorious.

\section{Conclusion}

Švejk, the phantom, exercises similar powers that he has exhibited as a hero of a literary fiction: Through the comic principle, he reveals how the war machine depends for its power on the seriousness with which we treat it. When denied importance and the cover of historical inevitability, war and the military as its instrument show themselves for what they mostly are-a means toward the achievement of banal political aims. In the twentieth century, Svejk has been a leading cultural idiom for the Czechs during the 30 years of German and Soviet military occupations. This unlikely literary hero was a crucial point of selfidentification for a nation disempowered and humiliated by military force, exemplifying the possibility of winning over absurdities of the military order through non-violent means. He was a source of that unique phenomenon that Michael Herzfeld calls cultural intimacy, a common reference that provides bond for bringing people within a culture together, while at the same time projecting a seemingly unfavorable image to the outsiders (Herzfeld 1997). The Czechs, a nation living under military occupation identified themselves and have become identified by the outside world with the cultural idiom of Svejk - the anti-hero, an "idiot" who triumphs over the war machine through words, self-ridicule, and laughter.

At the beginning of the twenty-first century, the joining of the transnational military alliance of NATO to which the Czech political representation tied the country's future required extensive changes both in the military sector and in the public sphere. The goal of these changes (promoted especially by the campaign for military professionalization) was to bring an image of seriousness to the discredited military, a process that demanded the obliteration of the cultural idiom of Švejk. These efforts, however, have brought Švejk so frequently to the public discourse that they produced a phantom-like effect in which Švejk has come to haunt the process directed at his expurgation. The established cultural idiom of skepticism toward the army and military bureaucracy challenged the transition from communism to democracy and questioned the reliance on military force, the imagery of violent conflicts, and just wars as necessary tools of politics.

\section{References}

Bakhtin, M. (1984). Rabelais and his world. Bloomington: Indiana University Press.

Cervinkova, H. (2005). Melancholic masculinity in the Czech military after socialism. In B. van Hoven \& K. Hörschelmann (Eds.), Spaces of masculinity. Oxford, New York: Routledge.

Cervinkova, H. (2006a). Playing Soldiers in Bohemia: An ethnography of NATO Membership. Set Out (Prague Series in Sociocultural Anthropology), Prague

Cervinkova, H. (2006b). Time to waste: Notes on the culture of the enlisted in the professionalizing Czech military. In F. Dauce \& E. Sieca-Kozlowski (Eds.), Dedovshchina in the post-Soviet military: Hazing of Russian Army conscripts in a comparative perspective. Hannover: Ibidem-Verlag.

Cervinkova, H. (2009). Migs and Cadres on the move: Thoughts on the mimetic dimensions of postsocialism. In L. Kürti \& P. Skalnik (Eds.), Postsocialist Europe: Anthropological perspectives from home. Oxford: Berghah.

Cottey, A., Edmuds, T., \& Forster, A. (2002). The second generation problematic: Rethinking democracy and civil-military relations in Central and Eastern Europe. Armed Forces and Society, 29, 31-56.

Deleuze, G., \& Guattari, F. (1987). 1227: Treatise on Nomadology-The war machine. In Thousand plateaus: Capitalism and schizophrenia (pp. 351-423). Minneapolis: University of Minnesota Press.

Gabal, I. (2001). Obrana - krize se prohlubuje. Neviditelný pes, April 2. 
Gabal, I. (2002). Atlantickou, nebo habsburskou cestou? Mladá fronta DNES, July 22.

Gabal, I., Helšusová, L., \& Szayna, T. (2002). The impact of NATO membership in the Czech Republic: Changing Czech views of security, military \& defence. Conflict Studies Research Centre. http://www. gac.cz/files/rep_cz.html.

Hašek, J. (1973). The good soldier Švejk. New York: Penguin.

Herzfeld, M. (1997). Cultural intimacy: Social poetics in the nation-state. New York: Routledge.

Jégl, P. (1997). Ceská diplomacie nemůže hledat zalíbení ve švejkovinách. Zemské noviny, September 2.

Kopecký, P. (1997). Skoncujme se švejkovstvím. Lidové noviny. March 7.

Mácha, P. (2001). Skupina Azalea. Aeronoviny, April 21.

Matynia, E. (2009). Performative democracy. New Haven: Yale University Press.

Michnik, A. (2003). Dziekujemy, Vaszku. Gazeta Wyborcza, January 2.

Ministry of Defense of the Czech Republic. (1999). Zákon č. 221/1999 Sb., o vojácích z povolání.

Ministry of Defense of the Czech Republic. (2001). Reforma ozbrojených sil Ceské republiky (The Reform of the Armed Forces of the Czech Republic). Prague: AVIS.

Ministry of Defense of the Czech Republic. (2002a). Nehrajem si na vojáky: Stručný návod, jak zvládnout reformu armády. Prague.

Ministry of Defense of the Czech Republic. (2002b). Cas něco udèlat. Prague.

Ministry of Defense of the Czech Republic. (2002c). Zitřek patrí profesionálüm: O reformě ozbrojených sil Ceské republiky. Prague: AVIS.

Růžička, M. (2001). Večer u Kalicha. Mladá Fronta DNES, February 22, p. 2.

Sedivý, J. (1999). The Kosovo test: Are the Czechs out? Newsbrief, 19(6), 43-45.

Simon, J. (1985). Warsaw pact forces: Problems of command and control. Boulder: Westview Press.

Simon, J. (1999). The new NATO members: Will they contribute? Strategic Forum, no. 160. Washington DC: National Defense University (Institute for National Strategic Studies).

Spurný, J. (1998). Vstoupili jsme do NATO: Ještě se ale neví, zda s tím budou členové souhlasit. Respekt, January 4.

Spurný, J. (2001). Stíhačka pro Švejka. Respekt, February 26.

Ulrich, M. (1999). Democratizing communist militaries: The cases of the Czech and Russian armed forces. Ann Arbor: The University of Michigan Press.

Ulrich, M. (2002). Developing mature national security systems in post-communist states: The Czech Republic and Slovakia. Armed Forces \& Society, 28(3), 403-425.

Vrána, K. (2001). Rambové versus švejci. Týden, October 8, 16-19.

Žantovský, M. (1999). Můžeme být za mírotvorce, ale i za švejky. Lidové noviny, March 11.

Žižka, J. (2001a). Češi z kola ven: Krizový scénář rozšífení EU. EURO, May 14.

Žižka, J. (2001b). Lacino a bez Čechů: Sance Prahy závisí na Polsku i ochote Západu. EURO, May 14. 